\title{
ANALISIS PENGARUH PENGELUARAN PEMERINTAH SEKTOR PENDIDIKAN DAN KESEHATAN TERHADAP KEMISKINAN DI JAWA TIMUR
}

\author{
Naylal Fithri \\ David Kaluge
}

PPIE Fakultas Ekonomi Universitas Brawijaya, nayla.fithri@gmail.com

\begin{abstract}
Poverty is a complex issue because it relates to the inability of access to economic, social, cultural, political and participation in society became one assessment of the success of the government's performance. This study aims to determine the effect of government spending for education and health sector to poverty. The data used is secondary data with regression models panel.Hasil mneguunakan Research shows that the effect of government spending education sector and no significant negative effect on poverty. Government spending in the health sector and no significant positive effect on poverty. This is because the government is less effective in reducing the number of people living below the poverty line, this is evidenced by the tendency of increase in the number of poor people from time to time.
\end{abstract}

Keywords: Government spending for education and health sector, poverty.

\begin{abstract}
Abstrak
Kemiskinan merupakan masalah kompleks karena berkaitan dengan ketidakmampuan akses secara ekonomi, sosial budaya, politik dan partisipasi dalam masyarakat yang menjadi salah satu penilaian dari keberhasilan kinerja pemerintah. Penelitian ini bertujuan untuk mengetahui pengaruh pengeluaran pemerintah disektor pendidikan dan kesehatan terhadap kemiskinan. Data yang digunakan adalah data sekunder dengan mneguunakan model regresi panel.Hasil Penelitian menunjukkan bahwa pengaruh pengeluaran pemerintah disektor pendidikan berpengaruh negatif dan tidak signifikan terhadap kemiskinan. Pengeluaran pemerintah disektor kesehatan berpengaruh positif dan tidak signifikan terhadap kemiskinan. Hal ini karena pemerintah masih kurang efektif dalam upaya menurunkan jumlah penduduk yang hidup di bawah garis kemiskinan, hal ini terbukti dengan adanya kecenderungan peningkatan jumlah penduduk miskin dari masa ke masa.
\end{abstract}

Kata Kunci: Pengeluaran pemerintah disektor pendidikan dan kesehatan, kemiskinan.

\section{PENDAHULUAN}

Kemiskinan menjadi persoalan yang

kompleks dalam suatu negara karena

kemiskinan tidak hanya berkaitan dengan masalah rendahnya tingkat pendapatan dan konsumsi, tetapi juga berkaitan dengan rendahnya tingkat pendidikan, kesehatan serta ketidakberdayaan masyarakat miskin untuk berpartisipasi dalam proses pembangunan. Secara umum, 
kemiskinan diartikan sebagai suatu keadaan di mana terjadi ketidakmampuan untuk memenuhi kebutuhan dasar seperti: makanan, pakaian, tempat tinggal, pendidikan, dan kesehatan. Sedangkan Badan Pusat Statistk (BPS) Indonesia mendefinisikan miskin adalah suatu kondisi kehidupan yang serba kekurangan yang dialami oleh seseorang atau rumah tangga sehingga tidak mampu memenuhi kebutuhan minimal atau layak bagi kehidupannya.

Penelitian yang dilakukan oleh Adi, Waridin dan Johanna tahun 2011 yang membahas mengenai evaluasi kebijakan susbsidi non-BBM terhadap pengentasan kemiskinan di Indonesia. Selain itu, berbagai upaya juga telah dilakukan Pemerintah Indonesia untuk mengentas kemiskinan yang terjadi di Indonesia selama ini. Namun, karena kurangnya proses evaluasi terkait kelemahan dan kelebihan dari setiap upaya tersebut membuat implementasinya kurang bisa dirasakan oleh masyarakat Indonesia. Oleh karena itu, perlu dilakukan kajian mendalam terkait aspek mana yang berpengaruh dan aspek mana yang tidak terlalu berpengaruh dalam mengentaskan kemiskinan di Jawa Timur. Hal ini diperlukan agar pemerintah bisa lebih fokus untuk bisa lebih mengoptimalkan aspek-aspek yang berpengaruh dalam rangka mengentaskan kemiskinan di Jawa Timur.

Jawa Timur merupakan salah satu provinsi di Indonesia yang terdiri dari 29 Kabupaten dan 9 Kota atau 38 Kabupaten/Kota dengan jumlah penduduk sebanyak 37.476.757 jiwa pada waktu dilakukan sensus penduduk tahun 2010. Banyaknya jumlah Kabupaten/Kota dan jumlah penduduk diprovinsi Jawa Timur ini dapat memberikan gambaran pembangunan manusia yang bervariasi dengan adanya penduduk miskin.

\section{Grafik 1. Jumlah Kemiskinan Jawa Timur Tahun 1999-2014}

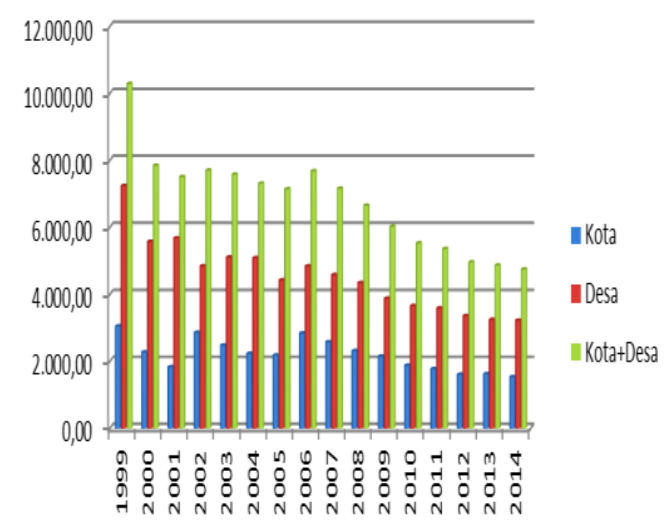

Sumber: Susenas 
Berdasarkan grafik diatas jumlah penduduk miskin di Jawa Timur selama 16 tahun terakhir mengalami penurunan yang signifikan baik daerah kota maupun daerah desa. Jumlah penurunan penduduk miskin pada periode 1999-2014 sebesar 5,54 juta jiwa, yaitu 10,28 juta jiwa $(29,47$ persen) pada tahun 1999 menjadi 4,47 juta jiwa $(12,28)$ pada tahun 2014.Dari gambaran di atas, terlihat bahwa kemiskinan masih menjadi permasalahan yang besar dan belum ditemukan solusi optimal yang bisa menyelesaikan masalah ini. Berdasarkan hal tersebut, maka kajian ini akan berfokus pada analisis mengenai pengaruh pengeluaran pemerintah di sektor pendidikan, sektor kesehatan, terhadap tingkat kemiskinan di Jawa Timur. Penulisan ini bertujuan untuk memberikan gambaran tentang pengaruh pengeluaran pemerintah di sektor pendidikan dan kesehatan terhadap tingkat kemiskinan di Jawa Timur sehingga diharapkan bisa menjadi gambaran bagi pemerintah dalam membuat kebijakan terkait upaya pengentasan kemiskinan yang sudah menjadi masalah lama di Jawa Timur.

\section{METODE PENELITIAN}

Penelitian ini merupakan penelitian deskriptif kuantitatif yang sifatnya memberikan gambaran secara umum, bahasan yang diteliti dalam data atau angka yang kemudian dianalisa, diklasifikasikan dan dipresentasikan dalam bentuk uraian. Metode pengumpulan data dengan cara dokumentasi yakni pengumpulan data dengan mencatat data yang dipublikasikan oleh lembaga atau instansi tertentu serta menyalin dokumen-dokumen yang relevan untuk digunakan dalam penelitian ini berasal dari Badan Pusat Statistik (BPS) Provinsi Jawa Timur dan Direktorat Jenderal Perimbangan Keuangan (DJPK). Waktu penelitian tahun 2010 sampai 2014. Model analisis yang digunakan adalah analisis regresi linier berganda dengan menggunakan program Eviews 7.

Menurut Jaya dan Sunaesih (2009), analisis regresi data panel adalah analisis regresi yang didasarkan pada data panel untuk mengamati hubungan antara satu variabel terikat (dependent variable) dengan satu atau lebih variabel bebas (independent variable). Ada tiga 
teknik yang bisa digunakan dalam regresi data panel yaitu teknik OLS (Common Effect), Fixed Effect dan Random Effect. Untuk menentukan teknik yang paling tepat untuk mengestimasi regresi data panel, harus melalui uji chow dan uji Hausman. Ketiga teknik yang digunakan untuk mengestimasi regresi data panel yaitu: common effect, fixed effect, dan random effect. Metode yang digunakan adalah:

$$
Y=\alpha+\beta_{1} \log X_{1}+\beta_{2} \log X_{2}+\varepsilon
$$

Dimana:

$$
\begin{array}{ll}
Y & =\text { kemiskinan } \\
\alpha & =\text { konstanta } \\
\beta_{1} & =\text { koefisien regresi dari } X 1 \\
\beta_{2} & =\text { koefisien regresi dari } X 2 \\
X_{1} & =\text { Pengeluaran pemerintah } \\
& \quad \text { sektor pendidikan } \\
X_{2} & =\text { Pengeluaran pemerintah } \\
& \text { sektor kesehatan } \\
\varepsilon & =\text { standart Error }
\end{array}
$$

\section{HASIL DAN PEMBAHASAN}

Pemilihan teknik estimasi model regresi data panel ada tiga model, yaitu metode OLS, model efek tetap dan model random. Pertanyaan yang muncul adalah teknik mana yang sebaiknya dipilih untuk regresi data panel dengan melalui uji chow dan uji Hausman. Uji chow untuk menguji antara model metode commond effect dan fixed effect dengan hipotesis sebagai berikut:

$\mathrm{H}_{0}$ : Common Effect Model

$\mathrm{H}_{1}$ : Fixed Effect Model

Dasar penolakan terhadap hipotesis diatas adalah dengan membandingkan perhitungan Fstatistik dengan F-tabel. Perbandingan dipakai apabila hasil $\mathrm{F}$ hitung lebih besar ( $>$ ) dari $\mathrm{F}$ table maka $\mathrm{H}_{0}$ ditolak yang berarti model yang paling tepat digunakan adalah Fixed Effect Model. Begitupun sebaliknya, jika $\mathrm{F}$ hitung lebih kecil $(<)$ dari $\mathrm{F}$ table maka $\mathrm{H}_{0}$ diterima dan model yang digunakan adalah Common Effect Model (Widarjono,2009).

Dari Hasil uji chow didapat nilai probabilitas Cross Section F dan Chi Square adalah 0.0000 yang lebih kecil dari Alpa 0.05 sehingga kita menolak $\mathrm{H}_{0}$. Jadi untuk uji chow, model pemilihan terbaik adalah model dengan Fixed Effect Model. Selanjutnya menguji antara Fixed Effect Model dengan Random Effect Model menggunakan uji hausman dengan hipotesis sebagai berikut: 
Apabila Hausman hitung $\geq$ Tabel Chi Square, maka H0 ditolak dan $\mathrm{Ha}$ diterima, berarti bahwa model Fixed Effect merupakan model yang tepat. Apabila Hausman hitung $\leq$ Tabel Chi Square, maka $\mathrm{H} 0$ diterima dan $\mathrm{Ha}$ ditolak, berarti bahwa model Random Effect merupakan model yang tepat. Dari hasil uji hausman didapat Probabilitas Cross Section Random sebesar 0.2950 lebih besar dari Alpha 0.05 sehingga kita menerima $\mathrm{H}_{0}$. Jadi untuk uji hausman, model pemilihan terbaik adalah model dengan Random Effect Model.

Pengujian yang selanjutnya yakni uji parsial (uji t) dengan tujuan untuk menguji pengaruh variabel bebas yaitu pengeluaran pemerintah disektor pendidikan dan kesehatan terhadap variabel kemiskinan dengan pengambilan keputusan sebagai berikut:

- Jika probabilitas $\mathrm{t}$ hitung $\leq \alpha$ (0.05), dimana $\alpha$ merupakan besarnya kesalahan yang ditolerir di dalam pengambilan keputusan maka $\mathrm{H}_{0}$ ditolak dan $\mathrm{H}_{1}$ diterima.

- Jika probabilitas $\mathrm{t}$ hitung $\geq \alpha$ (0.05), diamana $\alpha$ merupakan besarnya kesalahan yang ditolerir di dalam pengambilan keputusan maka $\mathrm{H}_{0}$ diterima dan $\mathrm{H}_{1}$ ditolak.

Dari hasil uji t menggunakan pendekatan fixed effect dapat diketahui bahwa Variabel X1 adalah -0.023245 dengan t-statistic 1.883390 dan signifikasi sebesar $0.0616>0.05$, Hal ini menunjukkan bahwa pengaruh pegeluaran pemerintah disektor pendidikan terhadap kemiskinan adalah negatif tidak signifikan. Variabel X2 adalah 0.001913 dengan dengan t-statistic 0.133561 dan signifikasi sebesar $0.8979>0.05$, Hal ini menunjukkan bahwa pengaruh pegeluaran pemerintah disektor kesehatan terhadap kemiskinan adalah posistif tidak signifikan.

$$
\text { Berdasarkan uji }
$$
statistik $F$ tabel pada model fixed effect, output regresi menunjukkan nilai signifikasi $0.000<0.05$, sehingg a dapat disimpulkan bahwa secara bersama-sama variabel PPP dan PPS berpengaruh secara signifikan terhadap variabel kemiskinan. Selanjutnya yakni analisis koefisien determinasi yang digunakan untuk mengetahui persentase PPP dan PPS terhadap Kemiskinan. Berdasarkan hasil regresi model fixed effect dapat 
diketahui adjusted R-squared sebesar 0.703307 artinya secara bersamasama variabel PPP dan PPS mempunyai kontribusi menjelaskan Kemiskinan sebesar $\quad 70.33 \%$ sedangkan sisanya $20.67 \%$ dijelaskan oleh variabel lain diluar model.

\section{KESIMPULAN DAN SARAN}

Penelitian ini bertujuan untuk melihat dampak dari pengeluaran pemerintah disektor pendidikan dan kesehatan terhadap kemiskinan di Jawa Timur. Sesuai dengan tujuan pemerintah yang diharapkan untuk dapat mengurangi angka kemiskinan . Namun hasil penelitian ini menunjukkan hal yang berbeda. Untuk variabel pengeluaran pemerintah disektor pendidikan memiliki dampak negatif dan tidak signifikan terhadap kemiskinan. Hasil ini menunjukkan bahwa pengeluaran pemerintah disektor pendidikan tidak tepat sasaran dalam membantu masyarakat miskin dalam memperoleh pendidikan yang layak. Selanjutnya variabel pengeluaran pemerintah disektor kesehatan memiliki dampak positif dan tidak signifikan terhadap angka kemiskinan yang berarti bahwa setiap penambahan pengeluaran pemerintah disektor kesehatan sudah tepat sasaran dan tidak akan mengurangi kemiskinan di Jawa Timur. Hal tersebut terjadi karena tidak selarasnya peningkatan kesehatan masyarakat dengan jumlah lapangan pekerjaan yang baru sehingga akan menciptakan angka kelahiran yang tinggi.

Dari penelitian diatas, ada beberapa saran yang berkaitan dengan kemiskinan. Pertama, peran pemerintah baik pemerintah daerah maupun pemerintah pusat, khususnya pemerintah daerah harus memprioritaskan alokasi anggaran yang dianggap sangat erat kaitannya dengan kemiskinan. Kedua, Program peningkatan pendidikan dan kesehatan masyarakat sebaiknya dibarengi dengan peningkatan lapangan pekerjaan baru. Ketiga, pemerintah khususnya kementerian kesehatan harus lebih memperketat program Keluarga Berencana (KB) kepada masyarakat miskin.

\section{DAFTAR PUSTAKA}

Badan Pusat Statistik. 2009-2014. Statistik Keuangan Kabupaten/Kota 2009-2014. BPS Jawa Timur. 
Analisis Pengaruh Pengeluaran Pemerintah Sektor....(Fithri dan Kaluge)

Badan Pusat Statistik. 2012-2013.

Kemiskinan 2012-2013. BPS

Jawa Timur.

Badan Pusat Statistik 1999-2014. Indeks Pembangunan Manusia 1999-2014. BPS Jawa Timur.

Bastias, Desi Dwi. "Analisis Pengaruh Pengeluaran Pemerintah atas pendidikan, Kesehatan, dan Infrastruktur terhadap Pertumbuhan Ekonomi Indonesia Periode 1969-2009”. Skripsi. Fakultas Ekonomi, Universitas Diponegoro, Semarang, 2010.

Brata, Aloysius Gunadi. "Investasi Sektor Publik Lokal, Pembangunan Manusia, dan Kemiskinan”. Jurnal Lembaga Penelitian Universitas Atma Jaya Yogyakarta, 2005. tidak ada halaman.

Jaya, I. G. N. M., \& N. Sunengsih. 2009. Kajian Analisis Regresi dengan Data Panel. Prosiding Seminar Nasional Penelitian. Yogyakarta: Universitas Negeri Yogyakarta.

Junaidi, Arius. (2012). Analisis Pertumbuhan Ekonomi dan
Kemiskinan di Indonesia. Jurnal Kajian Ekonomi 1:1.

Nurcahyono,E.2014.Analisis

Pengaruh Investasi dan Tenaga

Kerja terhadap Pertumbuhan

Ekonomi antar Provinsi di

Indonesia Tahun 2007-2012.

Skripsi. Jember:Fakultas

Ekonomi Universitas Jember

Ratnasari, N. P. A. M. 2014. Aplikasi

Regresi Data Panel Dengan

Pendekatan Fixed Effect Model

(Studi Kasus: PT PLN

Gianyar). Jurnal Matematika

FMIPA Universitas Udayana, 3(1): 1-7.

Widodo, Adi, Waridin dan Johanna Maria K. "Analisis Pengaruh Pengeluaran Pemerintah di Sektor Pendidikan dan Kesehatan Terhadap Pengentasan Kemiskinan Melalui Peningkatan Pembangunan Manusia di Provinsi Jawa Tengah. Semarang". Jurnal Dinamika Ekonomi Pembangunan, 1(1), Juli 2011, hal. 25-42.

Yuli Arifin , Mochammad.2013. Pengaruh pengeluaran Pemerintah Sektor kesehatan 
Analisis Pengaruh Pengeluaran Pemerintah Sektor....(Fithri dan Kaluge)

dan Pengeluaran Pemerintah

Sektor Pendidikan dan

Pertumbuhan

Ekonomi

Terhadap Indeks Pembangunan
Manusia Jawa Timur. Skripsi.

Jember: Fakultas Ekonomi

Universitas Jember. 